\title{
Designing wetlands for amphibians: The importance of predatory fish and shallow littoral zones in structuring of amphibian communities
}

\author{
Deni Porej and Thomas E. Hetherington \\ Department of Evolution, Ecology and Organismal Biology, The Ohio State University
}

\begin{abstract}
Under£401 and£404 of the Clean Water Act, permission to degrade existing natural wetlands in the USA may be conditional on restoring or creating "replacement" wetlands. Success of wetland mitigation efforts in adequately replacing lost wildlife habitats depends on our understanding of factors that affect the structure wetland faunal communities. We examined the effects of the presence of predatory fish, shallow vegetated littoral zone, emergent vegetation cover, and wetland age and size on amphibian diversity in 42 replacement wetlands located in the Ohio's Eastern Corn Belt Plains ecoregion. We recorded 13 species of pond-breeding amphibians, and the average local species richness (a-richness) was $4.2 \pm 1.7$ species per site (range 1-7). There is strong evidence for the positive association between amphibian species richness and presence of a shallow littoral zone, and the negative association with presence of predatory fish. There was no evidence for the association between species richness and age, size, nor the amount of emergent vegetation cover at the study sites. It is estimated that local species richness in wetlands with shallows was 1.76 species higher on average than in wetlands without shallows (95\% CI from 0.75 to 2.76). The presence of predatory fish was associated with an average reduction in species richness by an estimated 1.21 species (95\% CI from 0.29 to 2.11). Amphibian species associated with forested wetlands were either rare (eastern newt, spotted salamander) or not present at all (marbled salamander, wood frog) in replacement wetlands. We surveyed all replacement wetlands constructed under 401 in Ohio during the past decade, and found that predatory fish were present in $52.4 \%$ of the sites and that shallows were absent from $42.7 \%$ of the sites. Our results indicate that current wetland replacement practices could have a negative effect on the amphibian diversity within our region.
\end{abstract}

\section{Introduction}

Under $£ 401$ and $£ 404$ of the Federal Water Pollution Control Act and subsequent amendments (The Clean Water Act), the approval to fill, drain or otherwise degrade a wetland in the USA may be conditional on restoring, creating or enhancing wetlands to compensate for any unavoidable loss in wetland area and function. Replacement ("mitigation") wetlands are built with the intent to replace all of the functions of lost wetlands, including storm water detention, water purification, nutrient cycling, ground water recharge and wildlife habitat (National Wetland Policy Forum 1988, US Department of the Army and US Environmental Protection Agency 1990). However, replacement of wildlife habitat is usually not one of the functions monitored or regulated (National Research Council 1995, 2001). When wetland assessments involve animals, the primary consideration is waterfowl, other birds, or identifiable endangered/threatened species (National Research Council 2001).

Pond breeding amphibians are an integral part of wetland ecosystems, but usually do not fall into any of the abovementioned categories. Amphibians in the American Midwest have already suffered a major loss of habitat due to the conversion of nearly $90 \%$ of pre-settlement wetlands to agricultural uses (Dahl 1990). It is therefore critical that, whenever possible, we manage all remaining aquatic ecosystems in a manner consistent with amphibian conservation and use every opportunity to recreate quality amphibian habitat (Leja 1998). Success of wetland mitigation efforts in adequately replacing lost ecosystems, and perhaps even in creating higher quality habitats than the impacted wetlands, is partially dependent on a better understanding of those wetland features that are important in structuring the composition of wetland-dependent faunal communities.

A National Research Council study (National Research Council 2001) concluded that hydrological variability is often not established in replacement wetlands, and concerns about not meeting the hydrological criteria used to define wetlands in the permitting process often encourages construction of permanently flooded open water wetlands. Studies of replacement wetlands in the Midwest (Galatowitsch and van der Valk 1996, Gallinugh 1998, Robb 2000, Porej 2003), and elsewhere around the USA (Campbell 1996, Magee et al. 1996), confirm this trend. In addition, average bank slopes of replacement wetlands were reported to be significantly steeper compared to natural reference wetlands in several studies (Fenessy 1997; Gallinugh 1998). Replacement of diverse natural wetlands with permanent open water wetlands may have a significant negative impact on wetland-dependent fauna. Wetlands with permanent standing water have more amphibian predators, including odonates, dytiscid beetles and predatory fish (e.g., Smith 1983, Woodward 1983, 
Skelly 1992, Skelly 1996, Wellborn et al 1996). Several studies suggest that fish predation affects the structure of amphibian communities (Hecnar and M'Closkey 1997, Adams 1999, Smith et al. 1999). Furthermore, steep blank slopes can potentially eliminate the shallow littoral zone, which provides suitable egg laying, foraging and refugia sites for pond-breeding amphibians.

We have investigated how presence of predatory fish and the absence of a shallow littoral zone affect the structure of amphibian communities of replacement wetlands in central Ohio. We predicted that the presence of a vegetated shallow littoral zone would have a positive effect on species richness, whereas the presence of predatory fish would be associated with a decrease in species richness. We predicted differential species-specific responses to these two variables due to differences in larval behavior (e.g. Woodward 1983, Petranka et al. 1987) and larval palatability (Kats et al. 1988) among the species studied.

\section{Study Sites}

In 2000 we compiled all available information on wetland replacement projects located within the Eastern Corn Belt Plains ecoregion of Central Ohio. Access permission was obtained for 42 wetlands, and these sites were included in our study. In 2001 we sampled 38 wetlands. In 2002 all but one site was re-sampled, and three new sites were added for a total of 41 sites. Based on the ongoing file review, we estimate that this number represents over $85 \%$ of all the wetlands constructed under individual $£ 401$ permits within this region.

Data on the surrounding landscape composition were obtained from National Land Cover Database and National Wetland Inventory maps using ARC GIS applications (Environmental Systems Research Institute 1998). Data were verified by field reconnaissance and review of aerial photographs of the wetlands and the surrounding areas taken in late 1990's. The dominant landuse within our study area is row-crop agriculture, and although $90 \%$ of Ohio was forested in pre-European settlement era, forest landcover is now generally $<10 \%$ across the entire ecoregion. The primary land use within the $200 \mathrm{~m}$ of the sites is row-crop agriculture (average $49.2 \pm 3.1 \%$, range $15-79 \%$ ) with scattered woodlots (average forest landcover $24.8 \pm 2.1 \%$, range $8-62 \%$ ).

We followed Hecnar and M'Closkey's (1997) classification of fish into predatory (centrarchids, eocids and salmonids) and non-predatory (cyprinids) categories. Only two wetlands had cyprinid fish only (fathead and mud minnows), which are not known to be important amphibian predators, and we groped these two sites with sites having no fish at all (sensu Hecnar and M'Closkey 1997). Bank slopes were calculated using elevation data collected along transects extending into the wetland and running parallel to the long and short axis of the wetland. Each transect was $15 \mathrm{~m}$ long and divided into three $5 \mathrm{~m}$ sections. "Shallows" are defined as areas with bank slopes of less than 15:1 over each of the three $5 \mathrm{~m}$ sections of the $15 \mathrm{~m}$ transect and vegetation cover of over 50\%. Total area and \% area covered by different vegetation types were calculated from vegetation maps made from available recent aerial photographs, GPS mapping, and field measurements collected using a Bushnell Yardage Pro" 500 Laser Rangefinder. Based on the presence of predatory fish and shallows, study sites were divided into four groups: Shallows/ No Fish ( $n=13$ ), Shallows/Fish ( $n=9$ ), No Shallows/No Fish $(\mathrm{n}=9)$ and No Shallows/Fish $(\mathrm{n}=11)$.

\section{Other replacement wetlands in Ohio}

In 2003-2003 we visited all replacement wetlands constructed under£401 in Ohio since 1990, for a total of 117 sites. We recorded the size, presence of shallows and predatory fish at all sites. Presence of a shallow littoral zone was determined using the method outlined above, and presence of predatory fish at these sites was established by dipnetting while wading through the wetlands $(\sim 1 / 2 \mathrm{~h})$, and by deploying two baited minnow traps for no less than $1 \mathrm{~h}$.

\section{Methods}

\section{Sampling techniques}

Amphibian surveys were conducted once during each of the three periods: 15 March-15 April, 15 May-10 June, and 20 June-10 July in 2001 and 2002. Each amphibian survey consisted of deployment of aquatic funnel traps, dip-netting, and visual surveys. In addition, four chorusing surveys were conducted during the last week of March, April, May and June, following the recommendations of the Ohio Frog and Toad Calling Survey (http://www.dnr.state.oh.us/ wildlife/resources/survey/index.html).

Aquatic funnel traps were made of aluminum and fiberglass window screen and had funnels at both ends that tapered from a $20 \mathrm{~cm}$ diameter to a $4 \mathrm{~cm}$ entrance hole. We followed recommendations by Adams et al. (1997) and placed two traps for the first $25 \mathrm{~m}^{2}$ of a particular habitat unit (e.g., open water, emergent, scrub-shrub), and added one more trap each time the area of the habitat unit doubled (e.g., a $100 \mathrm{~m}^{2}$ habitat patch received four traps). Habitats within the wetlands were classified as open water (which sometimes included submerged vegetation), emergent, shrub-scrub, and forested. The majority of study sites (38 out of 42) consisted only of emergent vegetation habitat (2-96\% of the total wetland area) and open water (20-90\% of the total wetland area). Four sites had a small scrub-shrub component (3-8\% of the total wetland area), and three study sites had a small forested component (3-7\% of the total wetland area) composed of mostly dead trees flooded during the wetland construction. Traps were retrieved approximately $24 \mathrm{hr}$ after deployment.

Dipnetting was done concurrently with funnel trapping at each wetland during each of the three sampling periods. Dip net sweeps were made in all habitat types for a minimum of 30 minutes per habitat type. Woody debris and other substrate materials were manually collected and searched 
for eggs and larvae. All adult and juvenile amphibians encountered while deploying or retrieving traps were hand captured (or the best effort was made), identified and released. Fish were captured in funnel traps and during dipnetting. Fish were captured in at least two survey periods per year in all wetlands that we classified as having predatory fish.

Chorusing surveys began $1.5 \mathrm{~h}$ after dusk and lasted 15 min at each site. Surveys concluded at midnight, and three to six sites were visited per night depending on the travel time between sites. Chorusing intensity was ranked from 0 to 3 as follows: no calls recorded (0), single male calling (1), multiple, but non-overlapping calls (2), and multiple, overlapping calls (3).

Capture of larvae or emigrating juveniles using funnel traps, dipnetting or captures during visual surveys was required for us to consider a species "present" at the site for the purposes of this study. The only exception is Blanchard's cricket frog for which we have recorded level 3 choruses at 5 sites, but caught tadpoles in only 3 sites. We considered Blanchard's cricket frog to be present at all five sites. Except for the abovementioned 3 localities for Blanchard's cricket frog, chorusing surveys did not add any new records, as we have captured tadpoles of all species for which we have recorded choruses. Tadpoles of American toads (Bufo americanus americanus) and Fowler's toads (Bufofowleri) are undistinguishable, and we separated these two species based on chorusing surveys and captures of adults.

\section{Statistical Analyses}

In order to calculate species turnover between the two study years we constructed a species-locality matrix for each year, and recorded the number of "unique" records (i.e., species recorded at a site in 2001 but not in 2002) for both 2001 and 2002. We then calculated the turnover percentage by dividing the sum of unique species-location records for 2001 and 2002 by the total number of specieslocality records in both years and multiplying that number by 100. A G-test with William's correction was used to test whether the distribution of individual species was significantly different between years.

We analyzed the association between the presence of shallows and predatory fish (as effects) with local amphibian species richness (as a response variable) using a univariate general linear model (GLM, SPSS 1998) with \% forest landcover within $200 \mathrm{~m}$ (\%FOR200), \% emergent vegetation cover (\%EMERG), wetland age and size as covariates. We used Levene's test of equality of error variances to check for model assumptions regarding equal error variance across groups.

Associations between the presence of individual species, presence of predatory fish, and presence of shallows were investigated using the 3-way G-test (Brown and Downhower 1988). This test allowed us to partition $\mathrm{G}_{\mathrm{T}}$ into components that corresponded to 3 pairwise (2-way) comparisons between these three binary variables and one 3-way joint interaction component. We had a sufficient sample size to test for species-specific effects of the study variables for 9 species (Table 3). "Species x Fish" and "Species x Shallow" are tests of the hypotheses that the presence of a particular species is independent of the presence of fish and the presence of shallows, respectively. The "Shallow x Fish" value was constant since it was determined by our initial choice of study sites (see Study Sites). Finally, "Species x Fish x Shallow" tested for joint interaction among the three factors. Each component was compared to the Chi-Squared distribution to test for independence. Averages are followed by \pm SE, unless noted otherwise. All analyses were performed using Minitab V.12.2 (Minitab Inc., 1998), except the 3way G-test, which was set up in Microsoft Excel.

\section{Results}

\section{Study sites}

A majority of our study sites were permanent wetlands $(81 \%)$, including all wetlands without a shallow littoral zone. There were no significant differences in the mean age $\left(\mathrm{F}_{(3,38)}=2.1, \mathrm{p}=0.11\right), \operatorname{size}\left(\mathrm{F}_{(3,38)}=2.0, \mathrm{p}=0.12\right)$ or $\%$ FOR200 $\left(\mathrm{F}_{(3,38)}=0.67, \mathrm{p}=0.57\right)$ between wetlands grouped based on the presence of shallows and predatory fish (Table 1). Wetlands with shallows had significantly higher $\%$ emergent vegetation coverage than wetlands without shallows (95\% CI of the difference $8.7-35.0 \%$ ).

\section{Other replacement wetlands in Ohio}

Of 117 replacement wetlands visited, 6 sites had no standing water. Predatory fish were present in $60.3 \%$ of all the sites greater than $1 \mathrm{ha}$, and in $39.4 \%$ of the replacement wetlands smaller than 1 ha. Overall, predatory fish were present in 52.4\% of replacement wetlands. Shallow littoral zone was present at $52.9 \%$ of the replacement wetlands greater than 1 ha, and at $85.4 \%$ of the replacement wetlands less than 1ha. Overall, shallow littoral zone was present in only $57.3 \%$ of the replacement wetlands (Fig. 3).

\section{Species recorded}

We recorded 13 species of pond-breeding amphibians during the 2001/02 field seasons (Table 2). Average local species richness (a-richness) was $4.2 \pm 1.7$ species per site (range 1-7). We collected 168 species-locality records in 2001, and 164 in 2002, with species turnover between years of $3.9 \%$. None of the study species showed a significant difference in presence/absence at study sites between years based on G-tests with William's correction. Therefore, in the following analyses, data from both years are pooled, and species are considered as present at the site if larvae were recorded in any of the two study years.

\section{Effects of shallows and predatory fish on local amphibian species richness}

There is strong evidence for the association between local amphibian species richness (Fig. 1) and both SHALLOW $\left(\mathrm{F}_{(1,35)}=12.53, P<0.001\right)$ and FISH $\left(\mathrm{F}_{(1,35)}=\right.$ 
Table 1. Characteristics of 42 study replacement wetlands grouped based on the presence of shallows (SHALLOWS) and predatory fish (FISH). Permanent sites did not dry out during the course of our study. None of the non-permanent sites dried out before July $10^{\text {th }}$ (conclusion of the sampling period) during either of the two years

\begin{tabular}{lllllll}
\hline Group & $N$ & Permanent & Age (years) & Size (ha) & $\%$ FOR200 & $\%$ \%MERG \\
\hline FISH/ NO SHALLOWS & 11 & $11(100 \%)$ & $5.8 \pm 0.7$ & $1.3 \pm 0.3$ & $20.3 \pm 2.9$ & $15.1 \pm 4.0$ \\
NO FISH/ NO SHALLOWS & 9 & $9(100)$ & $4.8 \pm 0.8$ & $1.6 \pm 0.5$ & $26.1 \pm 5.2$ & $23.7 \pm 6.5$ \\
FISH/ SHALLOWS & 9 & $6(67 \%)$ & $4.2 \pm 0.8$ & $1.9 \pm 0.3$ & $28.7 \pm 4.5$ & $38.1 \pm 6.9$ \\
NO FISH/ SHALLOWS & 13 & $8(62 \%)$ & $4.1 \pm 0.5$ & $0.9 \pm 0.2$ & $24.7 \pm 4.5$ & $43.1 \pm 7.9$ \\
Total & 42 & $34(81 \%)$ & $4.8 \pm 0.4$ & $1.4 \pm 0.2$ & $24.8 \pm 2.1$ & $30.4 \pm 3.6$ \\
\end{tabular}

Table 2. Pond-breeding amphibians recorded in 42 replacement wetlands in the Eastern Corn Belt Plains ecoregion of central Ohio.

\begin{tabular}{lll}
\hline Species recorded & & \% Occurrence \\
\hline American toad & Bufo americanus americanus & 50.0 \\
Fowler's toad & B. fowleri & 7.1 \\
Green frog & Rana clamitans & 73.8 \\
Northern leopard frog & R.pipiens & 76.2 \\
American bullfrog & R. catesbeiana & 54.8 \\
Spring peeper & Pseudacris crucifer & 52.4 \\
Western chorus frog & P. triseriata & 23.8 \\
Gray treefrog & Hyla versicolor & 47.6 \\
Blanchard's cricket frog & Acris crepitans blanchardii & 11.9 \\
Tiger salamander & Ambystoma tigrinum & 4.8 \\
Spotted salamander & A. maculatum & 4.8 \\
Small-mouthed salamander & A. texanum & 14.3 \\
Eastern newt & Notophthalamus viridescens & 2.4 \\
& &
\end{tabular}

Table 3. Distribution of nine amphibian species in relationship to the presence of a shallow littoral zone (Shallows) and predatory fish (Fish) within 42 replacement wetlands in central Ohio. Values from 3-way G test, except for western chorus frogs and small-mouthed salamanders that were not breeding in any wetlands with predatory fish (two-way G-test with Williams' correction). Positive association between species presence and variable indicated by $(+)$, negative association by $(-)$.

\begin{tabular}{lccccc}
\hline Species & Species x Fish & Species $\times$ Shallow & Fish $\times$ Shallow & Species $\times$ Fish $\times$ Shallow & $\mathrm{G}_{\mathrm{T}}$ \\
\hline American toad & 3.13 & $3.89^{*}(+)$ & 1.98 & $19.01^{* *}$ & 28.05 \\
American bullfrog & 2.21 & 2.21 & 1.98 & $6.96^{*}$ & 13.10 \\
Green frog & 2.43 & $0.41^{* *}$ & 1.98 & 2.79 & 7.61 \\
N. leopard frog & 0.20 & $6.95^{* *}(+)$ & 1.98 & 0.06 & 9.20 \\
Spring peeper & $7.25^{* *}(-)$ & $1.98^{*}$ & 1.98 & 0.63 & 11.84 \\
W. chorus frog & Absent & $5.28^{*}(+)$ & & 0.87 & 8.60 \\
Gray treefrog & 1.34 & $6.14^{*}(+)$ & 1.98 & 1.16 & 4.80 \\
B. cricket frog & 0.24 & $1.42^{* *}$ & 1.98 & &
\end{tabular}

${ }^{*} P<0.05,{ }^{* *} P<0.01$ based on a Chi-Square Distribution 
7.21, $P=0.011)$. There was no evidence for the association between species richness and $\operatorname{AGE}\left(\mathrm{F}_{(1,35)}=1.42, P=0.24\right)$, SIZE $\left(\mathrm{F}_{(1,35)}=1.02, P=0.31\right)$, \%FOR200 $\left(\mathrm{F}_{(1,35)}=0.19\right.$, $P=0.66)$ nor $\%$ EMERG $\left(\mathrm{F}_{(1,35)}=1.36, P<0.25\right)$. None of the interaction terms in the model were statistically significant. It is estimated that local species richness in wetlands with shallows was 1.76 species higher on average than in wetlands without shallows (95\% CI from 0.75 to 2.76). The presence of predatory fish was associated with an average reduction in species richness by an estimated 1.21 species (95\% CI from 0.29 to 2.11). Wetlands with predatory fish and without shallows had significantly lower local species richness (average 2.63 species/site) than all other wetland types, except for the wetlands in NOFISH/NO SHALLOWS group. This group of study sites also had the lowest total number of species recorded (6 species). Wetlands with shallows and without the predatory fish had significantly higher average local species richness (6.16 species/site), than all other wetland types. This group also had the highest total number of species recorded (12 species, Fig. 3).

\section{Responses of individual species}

Amphibians exhibited differential responses to the presence of predatory fish and the presence of shallows (Table 3). The presence of American toads (Bufo americanus), northern leopard frogs (Rana pipiens), western chorus frogs (Pseudacris triseriata), gray tree frogs (Hyla versicolor) and small-mouthed salamanders (Ambystoma texanum) was positively associated with the presence of a shallow littoral zone in study sites. We did not have sufficient number of records to perform tests on Blanchard's cricket frogs (Acric crepitans blanchardii), but we recorded them only in wetlands with shallows. Although we detected no significant response to predatory fish for American toads, this species was recorded more commonly in fish-free wetlands (Species x Fish x Shallows term significant Table 3). Spring peepers (Pseudacris crucifer) were recorded at all four types of wetlands, and their presence was negatively associated with presence of predatory fish. We did not record western chorus frogs and small-mouthed salamanders (Ambystoma texanum) in wetlands that contained predatory fish, regardless of whether they had shallows or not. The only two wetlands where we captured tiger salamander (Ambystoma tigrinum) larvae, and two others where we captured spotted salamander (Ambystoma maculatum) larvae, also had no predatory fish. American bullfrogs (Rana catesbeiana) were most common in wetlands with predatory fish and without shallows, while green frogs (Rana clamitans) were ubiquitous and evenly distributed in all types of wetlands.

\section{Discussion}

Current criteria for successful wetland creation/ restoration during the 5-year post-construction monitoring period are based on the 1987 ACoE Wetland Delineation Manual (Environmental Laboratory 1987). These criteria are (a) sufficient periods of soil saturation (hydrology), (b) development of hydric soils, and (c) establishment of hydrophytic vegetation. Newly constructed wetlands with a permanent hydroperiod may have a lower risk of not satisfying the hydrology and soil criteria than a newly constructed wetland with seasonal hydrology (NRC 2001). A permanent hydroperiod in turn increases the probability that the site might harbor predatory fish. In addition, during a year with low precipitation, a shallow littoral zone may dry out and therefore not satisfy hydrology and soil criteria. Creation of pools with steep slopes maximizes the amount of wetland acres created per amount of land available and minimizes seasonal and year-to-year variations in the footprint of inundation (minimizing the risk of noncompliance due to insufficient wetland area created). The establishment of a narrow fringe of emergent plant species on these steep banks slopes fulfills the hydrophytic vegetation criteria (c). It is understandable then that we see an overrepresentation of open water (i.e., single, large pool), steep slopes and permanent hydroperiods in replacement wetlands (this study, see also Galatowitsch and van der Valk 1996, Gallinugh 1998, Robb 2000, Porej 2003b). This results in many wetlands providing suitable habitat for predatory fish, and a majority of them not having any shallow littoral zones, as our data on replacement wetlands in Ohio shows. Our results indicate that this approach to creating and replacing wetlands has a negative impact on maintaining amphibian diversity.

Wetlands without a shallow littoral zone and with predatory fish present resemble gamefish ponds in design (Illinois Department of Conservation 1995) and are suitable habitat only for a limited subset of amphibian species (see also Lanoo 1996). Amphibian communities in this wetland type were dominated by ranid frogs (American bullfrogs, green frogs and leopard frogs), with few records of spring peepers, gray treefrogs and American toads. Both American bullfrogs and green frogs produce large numbers of small eggs, possibly as an adaptation to predation (Wilbur 1984), have larvae that take a full year to develop, and are unpalatable to fish (Kats et al. 1988). Some studies have demonstrated a positive relationship between the presence of predatory fish and American bullfrogs mediated through indirect effects of lessening the predation on bullfrog larvae by aquatic insects (Smith et al. 1999, Adams et al. 2003). In our study American bullfrogs were most common in pond-like wetlands containing predatory fish, a result that is consistent with previous studies (Hayes and Jennings 1986, Thurow 1994).

American toad is another species whose distribution was independent of presence of predatory fish. American toad is an early colonizing species, and it is unpalatable to fish in all life stages (Licht 1968). Higher occurrence in wetlands with shallows may indicate that these areas form suitable breeding sites or refugia from predators such as the bullfrog (Smith 2002), and deserves further study.

Ambystomatid larvae are palatable to fish (Kats et al. 1988), and centrarchid fish have been documented to cause 


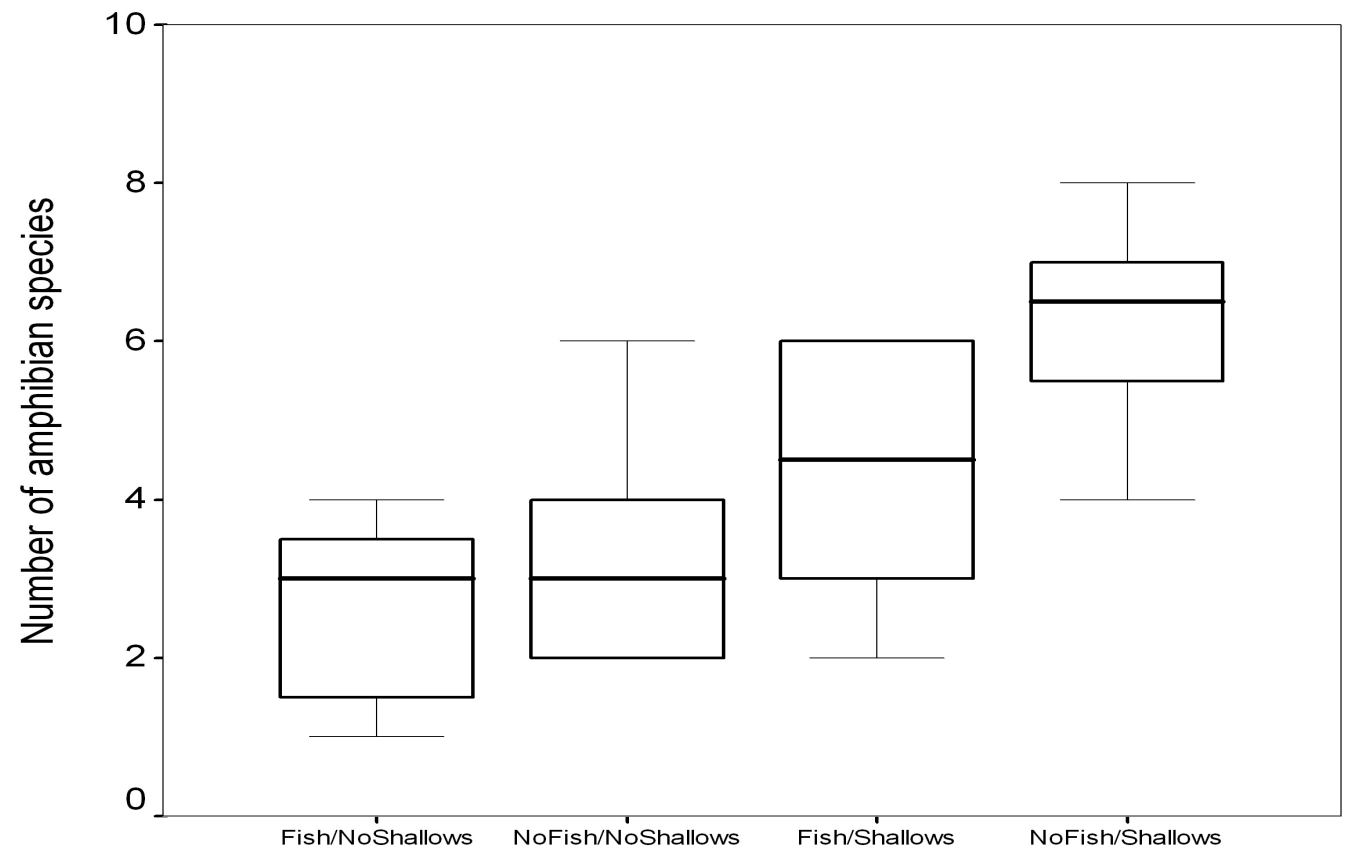

Figure 1. Box-and-whiskers plots (means, quartiles and extreme values within a category) of local amphibian species richness in 42 replacement wetlands differing in the presence of a shallow littoral zone (SHALLOWS) and presence of predatory fish (FISH) in central Ohio.

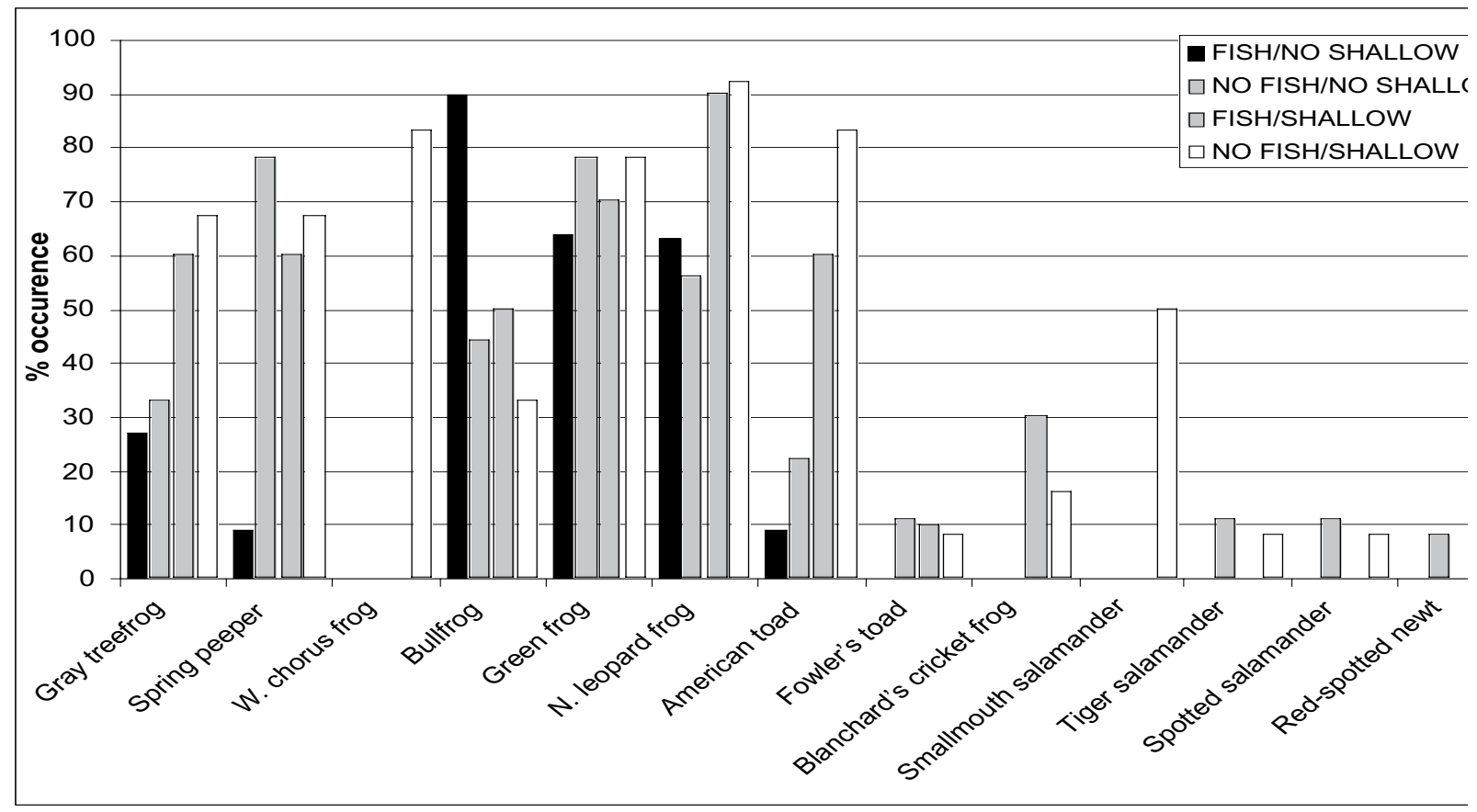

Figure 2. Distribution of amphibian species in 42 replacement wetlands in Ohio differing in the presence of predatory fish and a shallow littoral zone. 


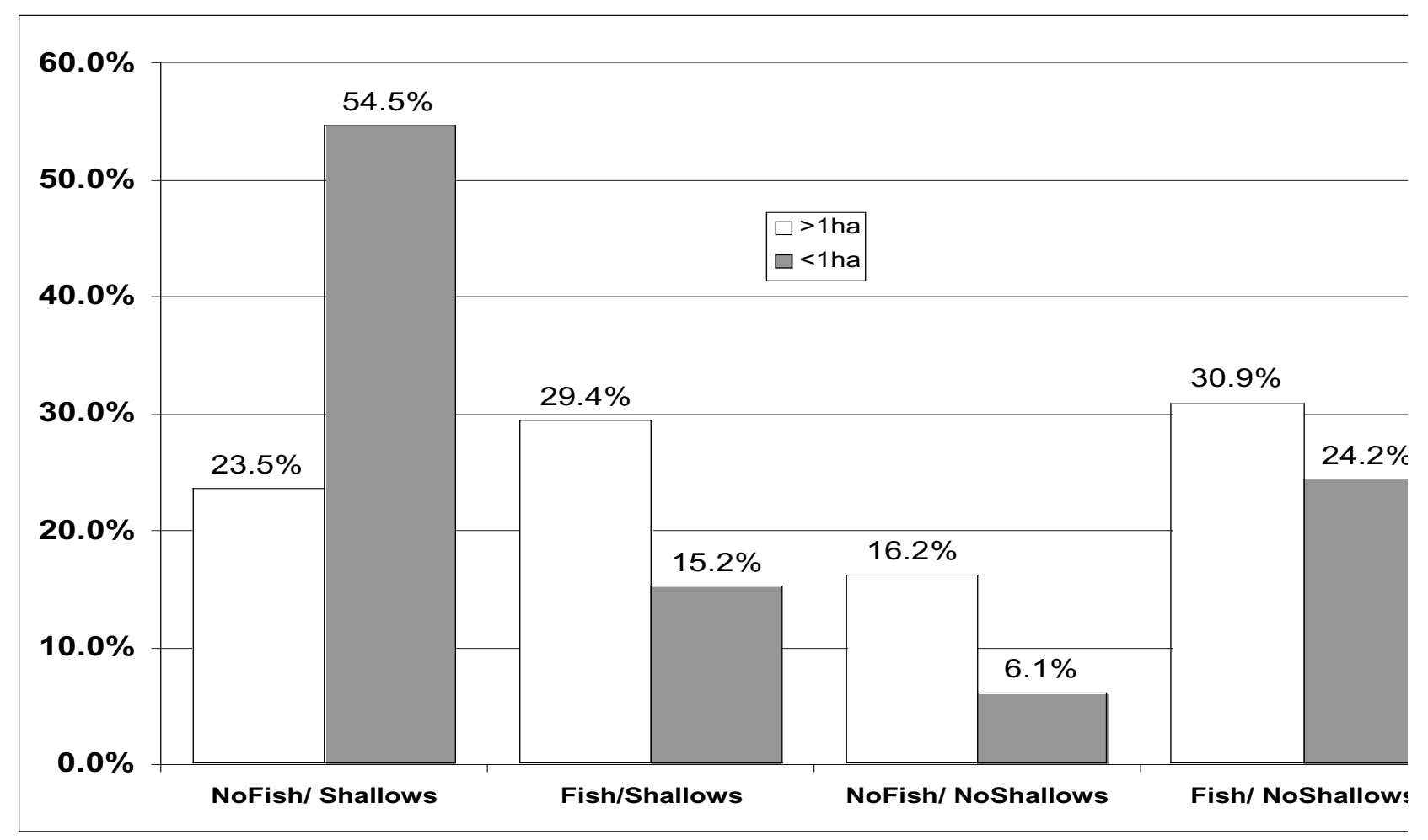

Figure 3. Distribution of 111 replacement wetlands in Ohio based on the presence of predatory fish (Fish) and the presence of a shallow littoral zone (Shallows). Sixty-eight wetlands were greater that 1 ha and forty-three were less than 1ha in size

local extirpation of small-mouthed salamander larvae (Petranka 1983). Other pond-breeding salamanders in our area may also respond to the presence of shallows and predatory fish. In ponds inhabited by bluegills, radio-tracked adult tiger salamanders (Ambystoma tigrinum) preferred shallow areas (Madison and Farrand 1998). Although interaction with fish might not be through predation, eastern newts (Notophthalmus viridescens) can be excluded from ponds with sunfish through competitive interactions (Bristow 1991, Smith et al. 1999).

Wetlands without shallows that do not harbor fish were used as breeding ponds by a wider group of species (10 vs. 6), but the local species richness in these wetlands remains low. Also, these are potentially suitable habitats for fish, and therefore are in danger of accidental or deliberate fish introductions (Porej, personal observation).

Presence of a shallow littoral zone was positively associated with presence of a number of species (American toads, western chorus frogs, leopard frogs, gray treefrogs, small-mouthed salamanders). Presence of shallows is associated with increases in amphibian diversity even in the presence of predatory fish (FISH/SHALLOW group). If consideration is given to amphibians during the process of designing and building a replacement wetland, these data suggest that fish-free wetlands with extensive shallow littoral zones should be the preferred design (NOFISH/SHALLOW group).

Replacement of numerous smaller wetlands with one, larger replacement wetland may be an additional negative management strategy for wetland-dependent herpetofauna. On average, 3.11 wetlands were impacted per wetland created for individual wetland projects in our study. If we assume that both impacted and created wetlands can be approximated by either a circle or a square, conversion of 3.11 wetlands into one wetland that is 1.5 times the cumulative area of impacted wetlands (replacement ratio of $1: 1.5$ ) results in loss of over $30 \%$ of wetland/upland boundary. Wetland-upland nexus is a critical area for wetland-dependent organisms, and "consolidation" of smaller wetlands into larger ones may further limit the functioning of replacement wetlands as quality amphibian habitat. In our study we failed to document significant association between local amphibian species richness (adiversity) and individual wetland size, and similar data exist for natural wetlands as well (Semlitsch and Bodie 1998, Snodgrass et. al 2000). Studies of other aquatic herpetofauna, such as aquatic snakes (Russel and Hanlin 1999, Roe and Kingsbury, unpublished) and turtles (Joyal et al. 2001), demonstrate that it is important to have different wetland types in close juxtaposition to provide adequate habitat for these organisms. We would therefore recommend that consolidation be avoided, and that several, diverse wetlands be created in lieu of one large wetland, especially if many wetlands are impacted during a project (see also Semlitsch 2000).

We did not document the presence of salamanders of the Jefferson's complex (Ambystoma jeffersonianum), wood frogs (Rana sylvatica), marbled salamanders (Ambystoma 
opacum) or four-toed salamanders (Hemidactlium scutatum) in any of the replacement wetlands. These species inhabit natural palustrine wetlands in central Ohio. Also, we recorded spotted salamanders and eastern newts at only two sites. All of these absent or rare species depend on the presence of upland forests to complete their life cycles (Gibbs 1998, Demaynadier and Hunter 1998, Guerry and Hunter 2002, Porej 2003). The low amounts of forest within the landscape surrounding our study sites may limit the number of potential colonizers, and be insufficient to support populations of these forest-associated species (Porej 2003). Disjunct distributions of these species throughout the Eastern Corn Belt Plains Ecoregion in Ohio indicate that most of these species were once widespread and were historically impacted by fragmentation and loss of forest habitat, including forested wetlands (Pfingsten and Downs 1989, Davis and Menze 2000). All of these species should be of some conservation concern, and careful planning of wetland design and landscape context of replacement wetlands (especially when forested wetlands are impacted) could help increase the probability of their continued survival in our region (Porej 2003).

\section{Acknowledgements}

We thank M. Micacchion and J. Mack for their help throughout this study, and A. Ullman for relentless help in fieldwork. We thank K. Richter, T. Waite, C. Caprette, M. Micacchion, and R. Semlitsch for reviewing the manuscript, and M. Lanoo, B. Kingsbury, J. Amon, W. Mitsch for helpful discussions and suggestions. Project was financially supported by grants from Ohio Environmental protection Agency and The Ohio Biological Survey.

\section{References}

Adams, M. J. 1999. Correlated factors in amphibian decline: Exotic species and habitat change in western Washington. Journal of Wildlife Management 63(4):1162-1171.

Adams, M. J., K. O. Richter, and W. P. Leonard. 1997. Surveying and monitoring amphibians using aquatic funnel traps. Pages 47-54 in Olson D. H, W. P., Leonard, and R. B. Bury, editors. Sampling amphibians in lentic habitats: methods and approaches for the Pacific Northwest. Society for northwestern vertebrate biology, Olympia, WA, USA.

Adams, M. J., Pearl C.A, and R.B Bury. 2003. Indirect facilitation of an anuran invasion by non-native fishes. Ecology Letters 6(4): 343-352.

Brown, L. and J. F. Downhower. 1988. Analyses in behavioral ecology. Sinauer Associates, Sunderland, MA, USA.

Campbell, D.A. 1996. Assessing the performance of created wetlands: a spatial and temporal analysis. MS thesis, Ecology Program. The Pennsylvania State University, University Park, PA, USA.
Dahl, T.E. 1990. Wetland losses in the United States 1780's to 1980's. US Fish and Wildlife Service, Washington, D.C., USA.

Davis, J. G. and S. A. Menze. 2000. Ohio Frog and Toad Atlas. Ohio Biological Survey Miscellaneous Contributions (6), Columbus, OH, USA.

Demanynadier, P. G. and M. L. Hunter Jr. 1998. Effects of silvicultural edges on the distribution and abundance of amphibians in Maine. Conservation Biology 12(2): 340352 .

Environmental System Research Institute. 1999. ArcView GIS version 3.2. Environmental System Research Institute, Redlands, CA, USA.

Fenessy, S. 1997. A functional assessment of mitigation wetlands in Ohio: comparisons with natural systems. Ohio Environmental Protection Agency Final Report, Division of Surface Water, Columbus, OH, USA.

Galatowitsch, S. M. and A. G. van der Valk. 1996. Characteristics of recently restored wetlands in the prairie pothole region. Wetlands 16(1):75-83.

Gallihugh, J. L. 1998. Wetland mitigation and 404 permit compliance study (Volume I). Final Report, US Fish and Wildlife Service Chicago Field Office, Barrington, IL, USA.

Gibbs, J. P. 1998. Distribution of woodland amphibians along a forest fragmentation gradient. Landscape Ecology 13:263-268.

Guerry, A. D., and M. L. Hunter Jr., 2002. Amphibian distributions in landscape of forests and agriculture: an examination of landscape composition and configuration. Conservation Biology 16(3):745-754.

Hayes, M.P., and M.R. Jennings. 1986. Decline of the ranid frog species in western North America: are bullfrogs (Rana cantesbeiana) responsible? Journal of Herpetology 20:490-509.

Hecnar, S. J. and R. T. M'Closkey. 1997. The effects of predatory fish on amphibian species richness and distribution. Biological Conservation 79:123-131.

Illinois Department of Conservation. 1995. Management of small lakes and ponds in Illinois. Illinois Department of Conservation, Division of Fisheries, Springfield, IL, USA.

Joyal, L. A., M. McCollough, and M. L. Hunter. 2001. Landscape ecology approaches to wetland species conservation: a case study of two turtle species in southern Maine. Conservation Biology 15(6):1755-1762.

Kats, L. B., J. W. Petranka, and A. Sih. 1988. Antipredator defenses and persistence of amphibian larvae with fishes. Ecology 69:1865-1870.

Lanoo, M.J. 1996. A fish fry: the role of exotic species and aquacultural practices in producing amphibian declines in the upper Midwest. Pp 25-27' in Moriarty, J.J., and D. Jones (eds.) Minnesota's amphibians and reptiles: 
conservation and status, Proceedings of Symposium, Serpent's Tale Press, Excelsior, MN, USA.

Leja, W.T. 1998. Aquatic habitats in the Midwest: waiting for amphibian conservation initiatives. Pp 345-353' in Lanoo, M. (ed.) Status and conservation of Midwestern amphibians. University of Iowa Press, Iowa City, IA, USA.

Licht, L.E. 1968. Unpalatability and toxicity of toad eggs. Herpetologica 24:93-98.

Magee, T. K., T. L. Ernst, M. E. Kentula, M. E. and K. A. Dwire. 1999. Floristic comparison of freshwater wetlands in an urbanizing environment. Wetlands 19(3):517-534.

Minitab Inc., 1998. Minitab statistical software, version 12.2.

National Research Council. 1995. Restoration of aquatic ecosystems: science, technology and public policy. National Academy Press, Washington, D.C., USA.

National Research Council. 2001. Compensating for wetland losses under the Clean Water Act. National Academy Press, Washington, D.C., USA.

National Wetlands Policy Forum. 1988. Protecting America's wetlands: an action agenda. The Conservation Foundation, Washington, D.C., USA.

Petranka, J. W., L. B. Kats, and A. Sih. 1987. Predator-prey interactions among fish and larval amphibians: use of chemical cues to detect predatory fish. Animal Behavior 35:420-425.

Pfingsten, R. A., and F.L. Downs, editors. 1989. Salamanders of Ohio. Bulletin of the Ohio Biological Survey 7(2). College of Biological Sciences, The Ohio State University, Columbus, OH, USA.

Porej, D. P. 2003. Faunal aspects of wetlands restoration. Ph.D. Thesis, The Ohio State University, Columbus, $\mathrm{OH}$.

Porej, D. P. 2003b. An inventory of Ohio compensatory wetland mitigation. Ohio Environmental Protection Agency report to US Environmental Protection Agency Region 5 Grant No.CD97576201-0. Ohio Environmental Protection Agency, Columbus, $\mathrm{OH}$.

Robb, J. T. 2000. Indiana Compensatory Mitigation Inventory. Final Report for EPA Grant \#CD985482010-0. Indiana Department of Environmental Management, Indianapolis, IN, USA.

Russel, K. R, and H. G. Hanlin. 1999. Aspects of the ecology of worm snakes associated with small isolated wetlands in South Caroloina. Journal of Herpetology 33(2):339-344.

Semlitsch, R. D. 2000. Principles of management of aquaticbreeding amphibians. Journal of Wildlife Management 64(3):615-631.

Semlitsch, R. D., and J. R. Bodie. 1998. Are small, isolated wetlands expendable? Conservation biology 12(5):1129-
1133.

Shaffer, B. H., R. A. Alford, B. D. Woodward, S. J. Richards, R. G. Altig, and C. Gascon. 1996. Quantitative sampling of amphibian larvae. Pages 130-141 in Heyer, W. R., M. A. Donnely, R. W. McDiarmid, L. C. Hayek, and M. S. Foster, (eds.) Measuring and monitoring amphibian diversity: standard methods for amphibians. Smithsonian Institution Press, Washington, D.C, USA.

Skelly, D. K. 1992. Field evidence for a cost of behavioral antipredator response in a larval amphibian. Ecology 73:704-708.

Skelly, D. K. 1995. Competition and the distribution of spring peeper larvae. Oecologia 103(2):203-207.

Skelly, D. K. 1996. Pond drying, predators and the distribution of

Pseudacris tadpoles. Copeia 1996:599-605.

Smith, D. C. 1983. Factors controlling tadpole population of the chorus frog (Pseudacris triseriata) on Isle Royale, Michigan. Ecology 64:501-510.

Smith, G. R., J. E. Rettig, G. G. Mittelbach, L. J. Valiulis, and S. R. Schaack. 1999. The effects of fish on assemblages of amphibians in ponds: a field experiment. Freshwater biology 41(4):829-837.

Snodgrass, J. W., M. J. Komorski, L. A. Bryan, and J. Burger. 2000. Relationships among isolated wetland size, hydroperiod, and amphibian species richness: Implications for wetland regulations. Conservation Biology 14(2):414-419.

SPSS. 1998. SYSTAT, Version 8.0. SPSS, Chicago, IL, USA.

Thurow, G.R. 1994. Suggested interim responses to the amphibian decline problem. Bulletin of the Chicago Herpetological Society 29:265-268.

US Department of the Army and US Environmental Protection agency. 1990. Unpublished Memorandum of Agreement concerning the determination of mitigation under the Clean Water Act Section 404 (b)(1) guidelines.

Wellborn, G. A., D. K. Skelly, E. E. Werner, D. G. Fautin. 1996. Mechanisms creating community structure across a freshwater habitat gradient. Annual review of ecology and systematics 27:337-363.

Wilbur, H. M. 1984. Complex life cycles and community organization in amphibians. Pages 195-224 in Price, P. W., C. N. Slobodchikoff, and W. S. Gaud, editors. A new ecology: novel approaches to interactive systems. John Wiley, New York, NY, USA.

Woodward, B. D. 1983. Predatory-prey interactions and breeding pond use of temporary-pond species in a desert anuran community. Ecology 64:1549-1555. 
150 The Olentangy River Wetland Research Park 